\title{
A New Genus of Apsilocephalidae (Diptera) in Mid-Cretaceous Burmese Amber
}

\author{
George Poinar Jr. ${ }^{a}$ \& Fernando E. Vega ${ }^{b^{*}}$ \\ ${ }^{a}$ Department of Integrative Biology, Oregon State University, Corvallis, Oregon, OR 97331, U.S.A. \\ ${ }^{\mathrm{b}}$ Sustainable Perennial Crops Laboratory, U. S. Department of Agriculture, Agricultural Research Service, \\ Beltsville, Maryland, MD 20705, U.S.A. \\ *Corresponding author. E-mail: Fernando.Vega@usda.gov
}

(C) The Authors 2021

\begin{abstract}
A new genus and species of apsilocephalid flies, Cascomixticus tubuliferous gen. et sp. nov. (Diptera: Asiloidea: Apsilocephalidae) is described from Burmese amber. Assignment to the Apsilocephalidae is based on the wing venation that is very similar to extant members of the family. The present fossil differs from known genera of this family by a long labellum bearing tactochemical papillae, a long tubular hypopharynx and a pointed labrum as well as the structure of the scape and pedicel. The long, tubular hypopharynx may have been used to obtain nectar from angiosperm flowers, however the function of the sharp-tipped labrum is unknown.
\end{abstract}

\section{ARTICLE HISTORY}

Received: $12-12-2020$

Revised: 9-02-2021

Accepted: 11-02-2021

\section{KEYWORDS}

Asiloidea

Burmese amber

Fossils

Myanmar

Taxonomy

\section{Introduction}

The Asiloidea represents a cosmopolitan superfamily of flies with variable habits. While the larvae are mostly predatory, the adults can be predaceous, herbivorous or both. Within the Asiloidea is the little-known family Apsilocephalidae with both extant and extinct representatives (Nagatomi et al., 1991; Gaimari \& Mostovski, 2000; Hauser \& Irwin, 2005; Winterton \& Irwin, 2008; Zhang et al., 2018).

The present study describes a new genus and species of the family Apsilocephalidae in Burmese amber. A unique character of the present fossil is its extended proboscis that is longer than the head, a long, tubular, porrect hypopharynx, a sharply pointed labrum and a labellum bearing tactochemical papillae.
Materials and methods

The amber specimen originated from the Noije Bum Summit Site mine in the Hukawng Valley, located southwest of Maingkhwan in Kachin State $\left(26^{\circ} 20^{\prime} \mathrm{N}, 9^{\circ} 36^{\prime} \mathrm{E}\right)$ in Myanmar. Based on paleontological evidence the site was dated to the late Albian of the Early Cretaceous (Cruickshank $\&$ Ko, 2003), placing the age at 97-110 million years ago (Mya). A more recent study determined the age to be $98.8 \pm 0.62$ Mya or at the Albian/Cenomanian boundary (Shi et al., 2012). Nuclear magnetic resonance spectra and the presence of araucaroid wood fibers in amber samples from the Noije Bum Summit Site indicate an araucarian tree source for the amber (Poinar et al., 2007).

Observations and photographs were made with a Nikon SMZ-10 R stereoscopic microscope and a Nikon Optiphot compound microscope with magnifications up to $1000 \mathrm{X}$. Helicon Focus Pro 
X64 was used to stack photos for better overall clarity and depth of field. Keys used for family identification, terms, including abbreviations for wing venation, were taken from Irwin and Lyneborg (1981), Nagatomi et al. (1991), Hauser and Irwin (2005), and Gaimari and Mostovski (2000). Syninclusions include a small midge (Diptera: Chironomidae) (Fig. 1) adjacent to the fossil.

\section{Systematic paleontology}

\section{Order: Diptera Linnaeus, 1758}

\section{Suborder: Brachycera \\ Infraorder: Asilomorpha}

Superfamily: Asiloidea

Family: Apsilocephalidae Nagatomi, Saigusa, Nagatomi, \& Lyneborg, 1991

\section{Genus: Cascomixticus gen. nov.}

LSID: urn:1sid:zoobank.org:act:4BA1D353356F-4EBE-98A2-3091C01834BE

Diagnosis: Female fly with long, porrect proboscis with extended, tubular hypopharynx, slender pointed labrum and setiferous labellum bearing protruding sensory papillae; palps 2segmented; eyes separated (dichoptic); ocelli 3, positioned on ocellar tubercle; pedicel longer than scape; postpedicel with single-articled, apically tapered stylus lacking a terminal process; wings hyaline except for diffuse dark stigma; Rs originating slightly distil to level of humeral cross vein; cell $\mathrm{m} 3$ closed and petiolate; cell $\mathrm{dm}$ complete, separated from cell bm that has three corners distally; tibial apex with pair of long setae; claws bifid at tip; arolium spine-like.

Etymology: Generic name from the Latin "casco" = old, and the Latin "mixticius" = mixed race in reference to the fossil possessing an elongate proboscis, which is a feature of species in many brachyceran families.

Cascomixticus tubuliferous gen. et sp. nov. (Figs. 1-12).

LSID: urn:1sid:zoobank.org:act:023F6068-C8704F67-8BAE-9A4E75BC812B
Holotype: Accession no. B-D-1-74 deposited in the Poinar amber collection maintained at Oregon State University.

Diagnosis: as for genus (monotypic)

Type locality: Myanmar (Burma), state of Kachin, Noije Bum Summit Site amber mine in the Hukawng Valley, SW of Maingkhwan

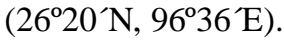

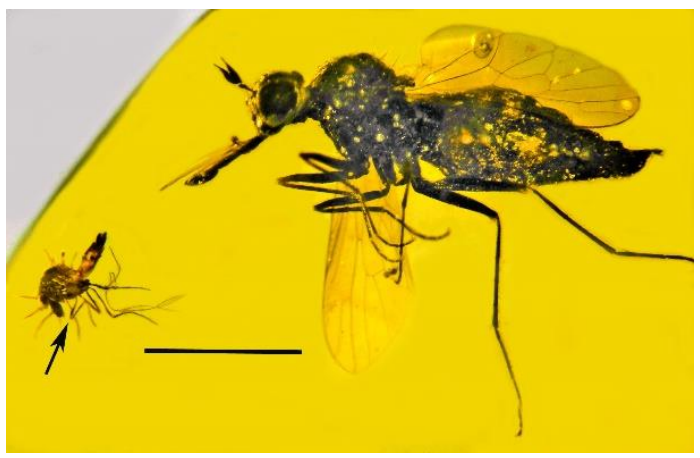

Figure 1. Left lateral view of Cascomixticus tubuliferous gen. et sp. nov. in Burmese amber. Arrow shows adjacent small midge (Diptera: Chironomidae). Scale bar $=1.5 \mathrm{~mm}$.

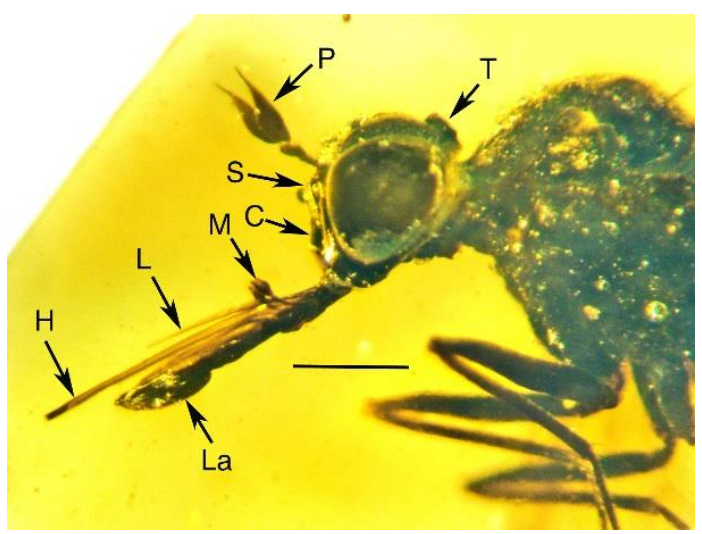

Figure 2. Left lateral view of head and pronotum of Cascomixticus tubuliferous gen. et sp. nov. in Burmese amber. $\mathrm{C}=$ clypeus; $\mathrm{H}=$ hypopharynx; $\mathrm{L}=$ labrum; $\mathrm{La}=$ labella; $\mathrm{M}=$ maxillary palps; $\mathrm{P}$ = postpedicel; $\mathrm{S}=$ face papillae; $\mathrm{T}=$ ocellar tubercle. Scale bar $=330 \mu \mathrm{m}$. 


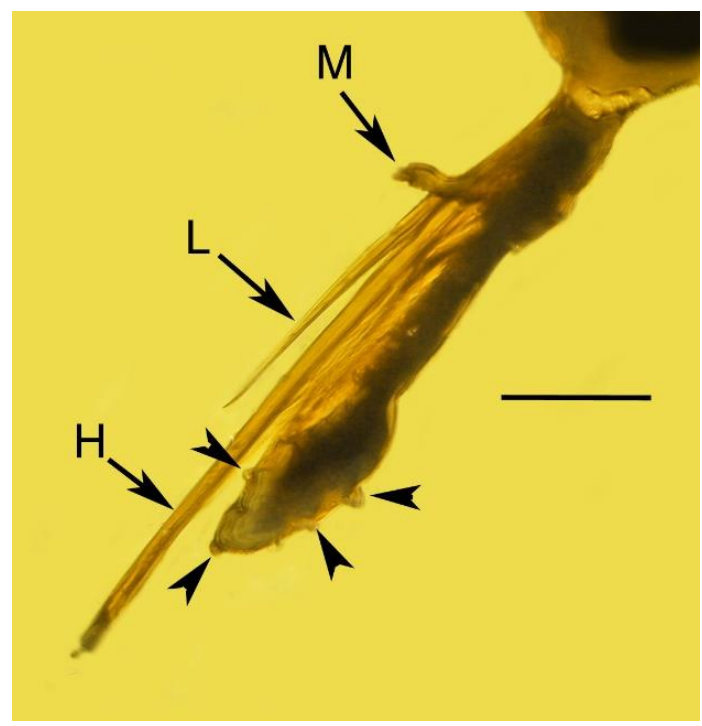

Figure 3. Lateral view of mouthparts of Cascomixticus tubuliferous gen. et sp. nov. in Burmese amber. $\mathrm{L}=$ labrum; $\mathrm{H}=$ hypopharynx; $\mathrm{M}=$ maxillary palps. Arrowheads show tactochemical papillae on labellum. Scale bar $=$ $200 \mu \mathrm{m}$.

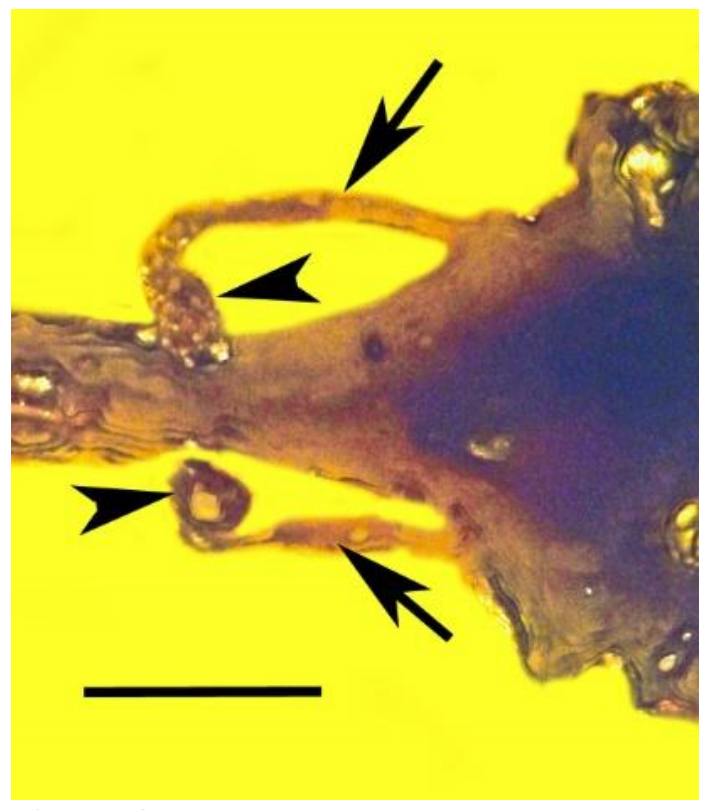

Figure 4. Dorsal view of maxillary palps of Cascomixticus tubuliferous gen. et sp. nov. in Burmese amber. Arrows show elongate basal segments; arrowheads show terminal globular segments. Scale bar $=250 \mu \mathrm{m}$.

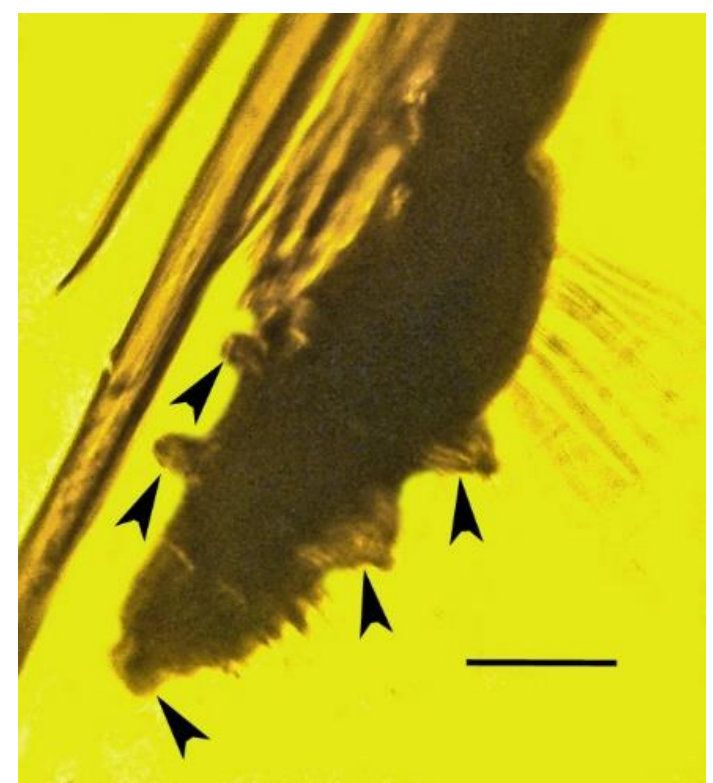

Figure 5. Detailed view of the labellum of Cascomixticus tubuliferous gen. et sp. nov. in Burmese amber showing tactochemical papillae (arrowheads). Scale bar $=65 \mu \mathrm{m}$.

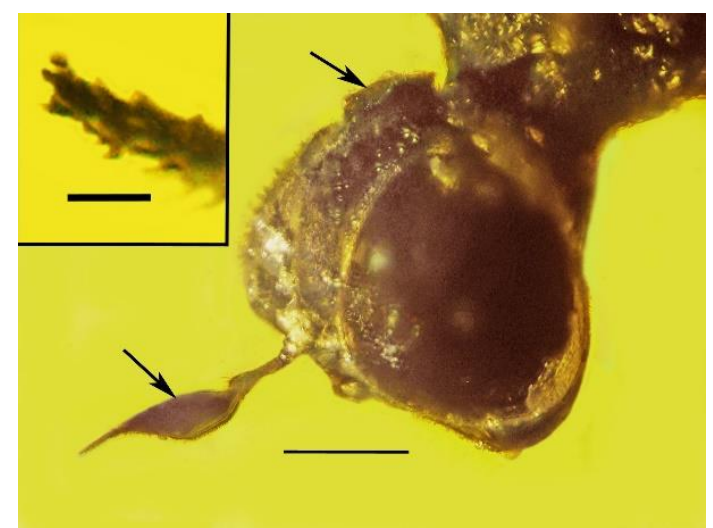

Figure 6. Head of Cascomixticus tubuliferous gen. et sp. nov. in Burmese amber. Note dichoptic eyes. Upper arrow shows ocellar tubercle. Lower arrow shows postpedicel with terminal stylus (second antennae image removed). Scale bar $=$ $180 \mu \mathrm{m}$. Insert shows tip of stylus. Scale bar $=10$ $\mu \mathrm{m}$. 


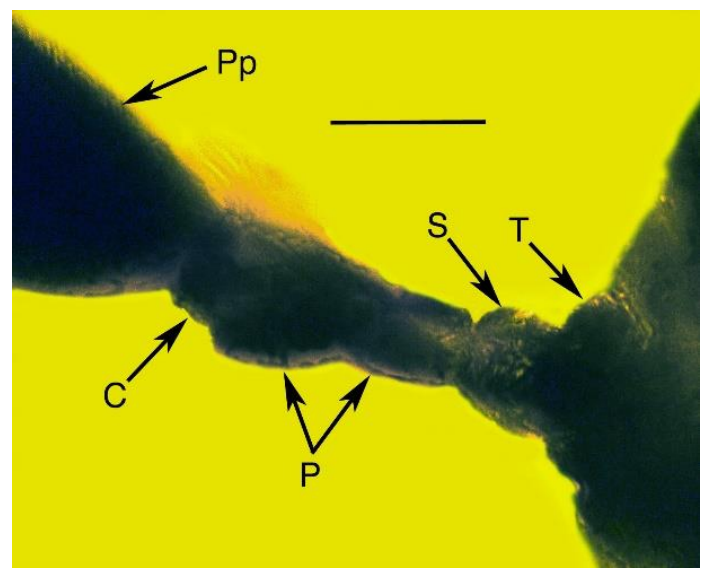

Figure 7. Base of antenna of Cascomixticus tubuliferous gen. et sp. nov. in Burmese amber showing torulus $(\mathrm{T})$; scape $(\mathrm{S})$; pedicel $(\mathrm{P})$ with narrow basal and swollen anterior portions; connective $(\mathrm{C})$ and postpedicel $(\mathrm{Pp})$. Scale bar = $35 \mu \mathrm{m}$.

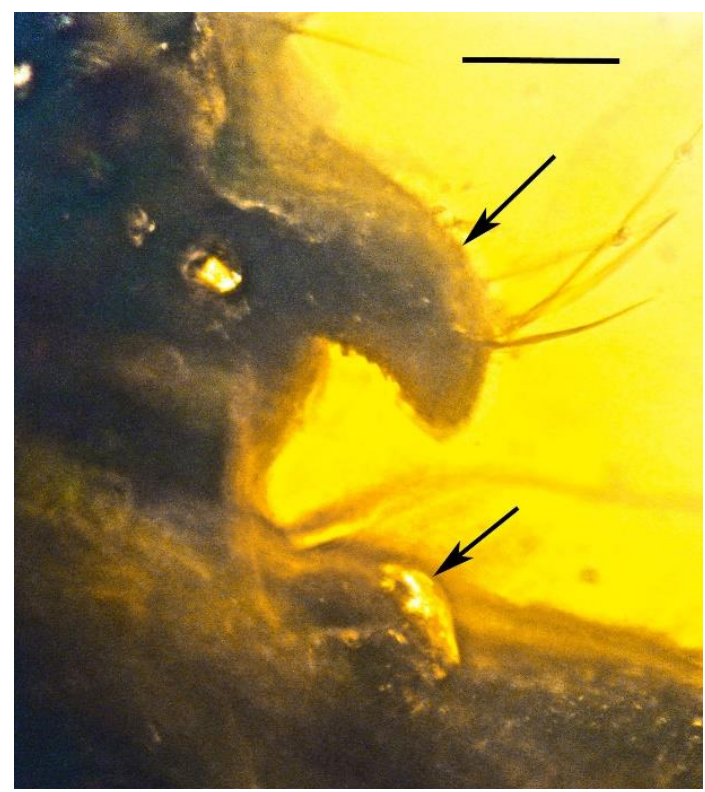

Figure 8. Scutellum (top arrow) and subscutellum (bottom arrow) of Cascomixticus tubuliferous gen. et sp. nov. in Burmese amber. Scale bar $=100 \mu \mathrm{m}$.

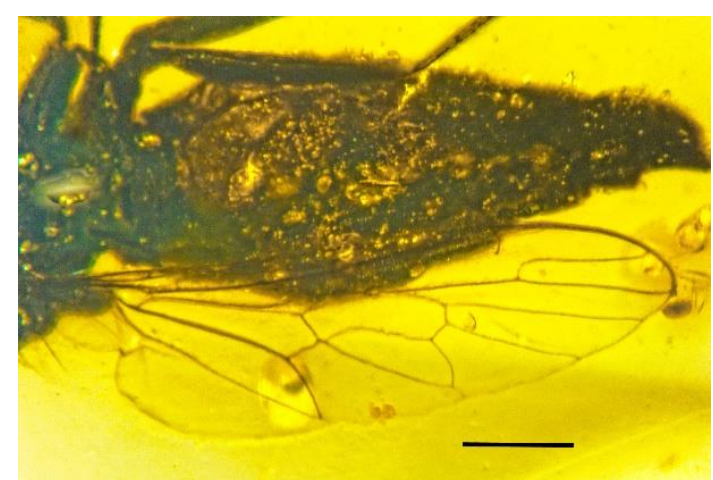

Figure 9. Right wing of Cascomixticus tubuliferous gen. et sp. nov. in Burmese amber. Scale bar $=400 \mu \mathrm{m}$.

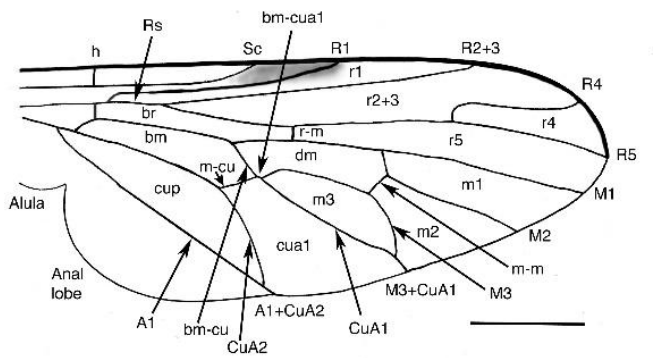

Figure 10. Wing venation of Cascomixticus tubuliferous gen. et sp. nov. in Burmese amber. Scale bar $=430 \mu \mathrm{m}$.

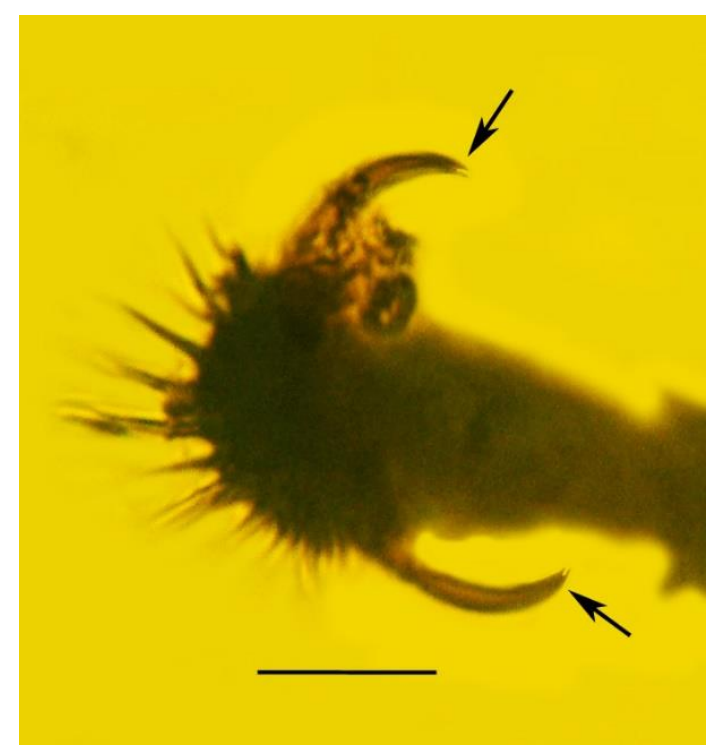

Figure 11. Metatarsal claws of Cascomixticus tubuliferous gen et sp. nov. in Burmese amber. Note setiferous tip of tarsomere. Arrows show minute bifurcation in tip of claws. Scale bar $=12$ $\mu \mathrm{m}$. 


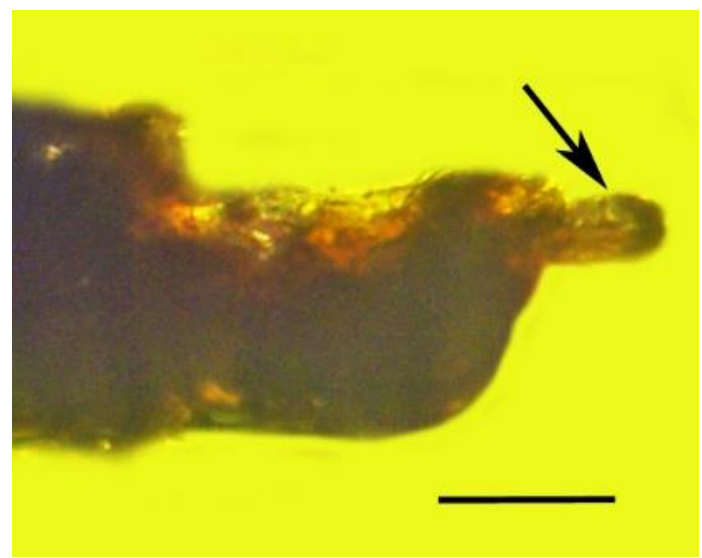

Figure 12. Tip of abdomen of Cascomixticus tubuliferous gen. et sp. nov. in Burmese amber. Arrow shows cercus. Scale bar $=70 \mu \mathrm{m}$.

Description. Body non-metallic, $4.5 \mathrm{~mm}$ long; head porrect, length (without proboscis), $550 \mu \mathrm{m}$; width head, $650 \mu \mathrm{m}$; eyes dichoptic, diameter eye, $420 \mu \mathrm{m}$; ocelli 3, positioned on ocellar tubercle $170 \mu \mathrm{m}$ in length on top of head; face flat with clypeus slightly protruding; short papillae on face beneath antennal insertions; proboscis $1.0 \mathrm{~mm}$ in length, longer than head length, porrect; length labium, $770 \mu \mathrm{m}$; length labellum, $290 \mu \mathrm{m}$; hypopharynx extended, not appearing protrusible, tube-like with blunt tip, length, $950 \mu \mathrm{m}$, with internal salivary canal; labrum slender, pointed, $600 \mu \mathrm{m}$ in length; palps 2-segmented, length 240 $\mu \mathrm{m}$, first segment elongated and acutely curved at apex, second segment globular; antennae $400 \mu \mathrm{m}$ long; torulus short, length $20 \mu \mathrm{m}$; scape short, length, $22 \mu \mathrm{m}$; pedicel with narrow basal and wider anterior portion; length both portions together, $60 \mu \mathrm{m}$; short connective $(\mathrm{L}=10 \mu \mathrm{m})$ between pedicel and postpedicel; postpedicel triangular-shaped, length, $280 \mu \mathrm{m}$; single-articled style approximately $90 \mu \mathrm{m}$ in length, mechanoreceptor on tip not obvious; thorax slender, length, $1.0 \mathrm{~mm}$; scutellum protruding, length, $200 \mu \mathrm{m}$; subscutellum small, protruding, length, $125 \mu \mathrm{m}$; wing hyaline except for diffusely darkened stigma between termination of veins $\mathrm{Sc}$ and R1; length wing, $2.5 \mathrm{~mm}$; costal termination at R5; vein R1 thickened, slightly swollen before joining $\mathrm{C}$; $\mathrm{R} 1$ meeting $\mathrm{C}$ slightly past mid-wing; Rs originating slightly distal to level of humeral cross vein; $\mathrm{R} 4+5$ and $\mathrm{M} 1+2$ meeting wing margin; base of vein $\mathrm{R} 4$ curved at 45 degree angle, then curved upwards at C; cell cup long; cells bm and dm closed, subequal in length, with cross vein complete; cell bm with three corners distally; cell $\mathrm{m} 3$ closed and petiolate; length of $\mathrm{Sc}$ vein 0.4 times wing length; stalk of $\mathrm{M} 3+\mathrm{CuA} 1$ vein approximately equal to $\mathrm{m}-\mathrm{m}$ cross vein; cross vein bm-cua1 horizontal; $\mathrm{R} 2+3$ meeting $\mathrm{C}$ about halfway between termination of R1 and R4; cell br complete; anal lobe convex, length, $750 \mu \mathrm{m}$; width, $300 \mu \mathrm{m}$; alular lobe convex, length, 280 $\mu \mathrm{m}$, width, $220 \mu \mathrm{m}$; halter large, length, $370 \mu \mathrm{m}$; length scale-like projection beneath halter, $8 \mu \mathrm{m}$; legs elongate, last pair of legs longer and wider than first two pairs; base of all tibia with a pair of long setae; length metafemur, $730 \mu \mathrm{m}$; length metatibia, $1.0 \mathrm{~mm}$; length metatarsus, $900 \mu \mathrm{m}$; tarsi 5-segmented with distal segment shortest; tip of $5^{\text {th }}$ tarsomere spinose; claws paired, with tips bifid; empodium spine-like; abdomen elongate, length, $2.5 \mathrm{~mm}$; cerci short, 1-segmented; length, $50 \mu \mathrm{m}$.

Etymology: Specific epithet is from the Latin "tubus" = pipe and the Latin "fero" = display, in reference to the long tubular, hollow hypopharynx.

Comments: Cascomixticus tubuliferous gen. et sp. nov. possesses a body shape and basic wing venation (including a $\mathrm{m} 3$ closed cell and long cup cell) typical of members of the Apsilocephalidae (Irwin \& Lyneborg, 1981; Nagatomi et al., 1991; Gaimari \& Mostovski, 2000; Hauser \& Irwin, 2005). The presence of a horizontal cross vein bm-cual and the hind leg longer and thicker than the other legs also align Cascomixticus with members of the Apsilocephalidae (Winterton \& Irwin, 2008).

\section{Discussion}

The family Apsilocephalidae contains the extant North American genus Apsilocephala Kröber (1914), the Tasmanian genera Clesthentia White (1914) and Clesthentiella Nagatomi, Saigusa, Nagatomi \& Lyneborg (1991) and the New Zealand genus Kaurimyia Winterton \& Irwin (2008). Apsilocephala has the antennal style much longer that the postpedicel; Clesthentia and Clesthentiella have vein R5 ending before the wing apex (Nagatomi et al., 1991); and Kaurimyia has the scape and pedicel wider than long and the antennal style deflexed ventrally at base (Winterton \& Irwin, 2008). None of the above genera have a proboscis longer than the head as in Cascomixticus.

Extinct genera of the family Apsilocephalidae described from Burmese amber include Burmapsilocephala cockerelli Gaimari \& Mostovski (2000), which has an antennal stylus 
2.5 times longer than combined antennal segments 1-3 and a proboscis less than the head length (Gaimari \& Mostovski, 2000), which distinguishes it from Cascomixticus. Also, from Burmese amber is Kumaromyia burmitica Grimaldi \& Hauser (Grimaldi et al. 2011); however, this species has a smaller body size ( $\mathrm{L}=$ $2.7 \mathrm{~mm}$ ) than $C$. tubuliferous $(\mathrm{L}=4.5 \mathrm{~mm})$, a onesegmented palp, minute second and third antennal articles, an incomplete apex of Sc, C ending between apices of R5 and M1, and the apex of M3 meeting the apex of $\mathrm{CuA}$ at the wing margin (Grimaldi et al., 2011). All these features separate $K$. burmitica from $C$. tubuliferous.

The Burmese amber Kuhwahldyia indefinita Solórzano Kraemer \& Cumming (2019), is described as being near the family Apsilocephalidae. However, in this species, veins M3 and $\mathrm{CuA} 1$ meet the wing margin separately, a stigma is absent, cell cup is open and $\mathrm{M}-\mathrm{Cu}$ vein is curved. Also, the mouthparts of Kuhwahldyia are smaller than those of Cascomixticus. The Burmese amber genus Myanmarpsilocephala Zhang et al. (2018) has a long arista-like stylus and open cell $\mathrm{m} 3$, which distinguishes it from Cascomixticus. The Burmese amber genus Irwinimyia Zhang et al. (2018) has cell bm with four corners distally, a thick stylus and the hind leg similar in size to the other legs, which distinguishes it from Cascomixticus (Zhang et al., 2018).

A single species of Apsilocephalidae, Apsilocephala vagabunda (Cockerell, 1927), was described from the Florissant Fossil Beds in Colorado, USA (Hauser \& Irwin, 2005). The pear-shaped postpedicel, short square pedicel, straight M3 vein, open br cell and absence of a horizontal bm-cua1 vein distinguishes $A$. vagabunda from Cascomixticus. While the extended mouthparts of Cascomixticus separate it from other apsilocephalids, an elongate proboscis has developed convergently in other families of orthorrhaphous Brachycera, including in species of Acroceridae, Apioceridae, Bombyliidae, Mydidae, Nemestrinidae, Tabanidae, Therevidae, Zhangsolvidae and Vermileonidae (Arillo et al., 2015). Such a proboscis can be used to obtain pollen and nectar from flowers but in the Tabanidae, the proboscises are also used to obtain vertebrate blood meals.

The mouthparts of Cascomixticus would appear to be adapted for both piercing and sucking although there is no way of knowing if the sharply pointed labrum could have been used to impale small invertebrate prey, thus the function of this structure remains unknown. The tubular hypopharynx of Cascomixticus could have been used to imbibe water, plant nectar and exudates from flowers, like the habits of adult therevids (Winterton et al., 2001; Hauser et al., 2017). Even if the nectar had dried, Cascomixticus could have released secretions from the long salivary duct within the hypopharynx to moisten the nectar before consuming it (Brown et al., 2009).

The sensory papillae on the labellum of Cascomixticus are interesting and appear to be a unique feature within the Asiloidea and Empidoidea (Cumming \& Sinclair, 2009). It is likely that they served as tactochemical receptors. The papillae on the face beneath the antennal insertions of Cascomixticus could be what Cole (1969) described as "shining callosities" on the upper face below the antennal bases of the therevid genus Chromolepida Cole. Cascomixticus tubuliferous presents novel features of an early lineage of the Asiloidea. These features add to the morphological diversity that existed in mid-Cretaceous Asilomorpha.

\section{Acknowledgements}

The authors thank Martin Hauser and Shaun L. Winterton for comments on a previous version of the manuscript.

\section{Conflict of interest statement}

No potential conflict of interest was reported by the authors.

\section{References}

Arillo, A., Peñalver, E., Pérez-de la Fuente, R., Delclòs, X., Criscione, J., Barden, P.M., Riccio, M.L. \& Grimaldi, D. (2015). Longproboscid brachyceran flies in Cretaceous amber (Diptera: Stratiomyomorpha: Zhangsolvidae). Systematic Entomology, 40 , 242-267. https://doi.org/10.1111/syen.12106

Brown, B.V., Borkent, A., Cumming, J.M., Wood, D.M., Woodley, N.E. \& Zumbado, M.A. (2009). Manual of Central American Diptera (Vol. 1). Ottawa, Canada: NRC Research Press.

Cockerell, T.D.A. (1927). Fossil insects from the Miocene of Colorado. The Annals and Magazine of Natural History, 9, 161-166. 
Cole, F.R. (1969). The Flies of Western North America. Berkeley: University of California Press.

Cruickshank, D. \& Ko, K. (2003). Geology of an amber locality in the Hukawng Valley, Northern Myanmar. Journal of Asian Earth Sciences, 21, 441-455. https://doi.org/10.1016/S13679120(02)00044-5

Cumming, J.M. \& Sinclair, B.J. (2009). Empididae (dance flies, balloon flies, predaceous flies). In B.V. Brown, A. Borkent, J.M. Cumming, D.M. Wood, N.E. Woodley \& M.A. Zumbado (Eds.), Manual of Central American Diptera (Vol. 1) (pp. 653-670). Ottawa: Canada NCR Research Press.

Gaimari, S.D. \& Mostovski, M.B. (2000). Burmapsilocephala cockerelli, a new genus and species of Asiloidea (Diptera) from Burmese amber. Bulletin of the Natural History Museum (London) Geology Series, 56, 41-44.

Grimaldi, D.A., Arillo, A., Cumming, J.M. \& Hauser, M. (2011). Brachyceran Diptera (Insecta) in Cretaceous ambers. Part IV, significant new orthorrhaphous taxa. Zookeys, $\quad 148, \quad 293-332$. https://doi.org/10.3897/zookeys.148.1809

Hauser, M. \& Irwin, M.E. (2005). Fossil Therevidae (Insecta: Diptera) from Florissant, Colorado (Upper Eocene). Journal of Systematic Palaeontology, 3, 393-403.

https://doi.org/10.1017/S14772019050016 90

Hauser, M., Winterton, S.L., Kirk-Spriggs, A.H. \& Holston, K.C. (2017). Therevidae (Stiletto Flies). In Kirk-Spriggs, A.H. \& B.J. Sinclair (Eds.), Manual of Afrotropical Diptera (Vol. 2) (pp. 11831208). Nematocerous Diptera and Lower Brachycera. Suricata 5. Pretoria, South Africa: South African National Biodiversity Institute.

Irwin, M.E. \& Lyneborg, L. (1981). Therevidae. In McAlpine, J.F., Peterson, B.V., Shewell, G.E., Teskey, H.J., Vockeroth, J.R. \& Wood, D.M. (Eds.), Manual of Nearctic Diptera (Vol. 1) (pp. 513-521). Monograph no. 27. Quebec: Canada: Canadian Government Publishing Centre, Hull.

Kröber, O. (1914). Beiträge zur Kenntnis der Thereviden und Omphraliden. Jahrbuch der Hamburgischen Wissenschaftlichen Anstalten, 31, 29-74.

Nagatomi, A., Saigusa, T., Nagatomi, H. \& Lyneborg, L. (1991). Apsilocephalidae, a new family of the orthorrhaphous Brachycera (Insecta, Diptera). Zoological Science, 8, 579-591.

Poinar, Jr., G.O., Lambert, J.B. \& Wu, Y. (2007). Araucarian source of fossiliferous Burmese amber: spectroscopic and anatomical evidence. Journal of the Botanical Research Institute of Texas, 1, 449-455.

Shi, G., Grimaldi, D.A., Harlow, G.E., Wang, J., Wang, J., Yang, M., Lei, W., Li, Q., \& Li, X. (2012). Age constraint on Burmese amber based on $\mathrm{U}-\mathrm{Pb}$ dating of zircons. Cretaceous Research, 37, 155-163. https://doi.org/10.1016/j.cretres.2012.03.0 $\underline{14}$

Solórzano Kraemer, M.M. \& Cumming, J.M. (2019). New genera of brachyceran flies (Diptera: Xylomyidae and Apsilocephalidae sensu auctorum) from mid-Cretaceous Hukawng Valley Burmese amber. Palaeoentomology, 002 (3), 251261.

https://doi.org/10.11646/palaeoentomolog y.2.3.10

White, A. (1914). The Diptera-Brachycera of Tasmania. Part I. Families Leptidæ, Stratiomyiidæ, Nemestrinidæ, and Cyrtidæ. Papers and Proceedings of the Royal Society of Tasmania, pp. 35-74.

Winterton, S.L., Yang, L., Wiegmann, B.M. \& Yeates, D.K. (2001). Phylogenetic revision of Agapophytinae subf. n. (Diptera: Therevidae) based on molecular and morphological evidence. Systematic Entomology, 26, 173-211. https://doi.org/10.1046/j.13653113.2001.00142.x

Winterton, S. \& Irwin, M.E. (2008). Kaurimyia gen. nov.: discovery of Apsilocephalidae (Diptera: Therevoid clade) in New Zealand. Zootaxa, 1779, 38-44. https://doi.org/10.11646/zootaxa.1779.1.3

Zhang, Q., Li, X., Xu, B., Zhu, Y., Lu, R., Wang, B. \& Yeates, D.K. (2018). Two new genera of Apsilocephalidae from mid-Cretaceous Burmese amber. Cretaceous Research, 84, 525-532. https://doi.org/10.1016/j.cretres.2017.11.0 $\underline{26}$ 
(c) $\Theta \Theta$ Publisher's note: Eurasia Academic Publishing Group (EAPG) remains neutral with regard to BY ND jurisdictional claims in published maps and institutional affiliations.

Open Access This article is licensed under a Creative Commons Attribution-NoDerivatives 4.0 International (CC BYND 4.0) licence, which permits copy and redistribute the material in any medium or format for any purpose, even commercially. The licensor cannot revoke these freedoms as long as you follow the licence terms. Under the following terms you must give appropriate credit, provide a link to the license, and indicate if changes were made. You may do so in any reasonable manner, but not in any way that suggests the licensor endorsed you or your use. If you remix, transform, or build upon the material, you may not distribute the modified material.

To view a copy of this license, visit https://creativecommons.org/licenses/by-nd/4.0/. 